\title{
RUMAH SENI RUANG TERAPI
}

\author{
Herman Suyudhi ${ }^{1)}$, Alvin Hadiwono ${ }^{2)}$ \\ 1)Program Studi S1 Arsitektur, Fakultas Teknik, Universitas Tarumanagara,hermansuyudhi66@gmail.com \\ 2)Program Studi S1 Arsitektur, Fakultas Teknik, Universitas Tarumanagara, alvinhadiwono@gmail.com
}

\begin{abstract}
Abstrak
Stress dan Depresi merupakan permasalahan yang sering terjadi dalam kehidupan masyarakat. Hal ini disebabkan oleh salah satunya kebiasaan manusia dalam menghabiskan sebagian besar waktunya bekerja dan beristirahat di rumah dan tanpa adanya kegiatan sosial yang dapat rutin dilakukan setiap hari dengan sesamanya, apalagi dengan adanya media sosial yang membuat manusia dapat berkomunikasi hanya dengan perangkat elektronik dan tidak bertemu secara langsung. Isu utama yang diangkat adalah "Open Architecture sebagai Third Place" yang membahas tentang bagaimana menciptakan sebuah tempat yang dapat menjadi Third Place sebagai tempat berkumpulnya komunitas masyarakat untuk bersosialisasi dan sebagai tempat publik informal. Isu lain yang di angkat adalah Seni Terapi sebagai Akses perubahan mental masyarakat yang mengalami tingkat stress berbeda dengan menggunakan seni dalam bentuk gambar, membagikan pikiran satu sama lain, menyadari diri melalui suatu objek, gerakan yang dapat disatukan dengan gambar dapat di jadikan ruang pentas seni. Lokasi proyek berada di Jalan RS. Fatmawati Raya di Jakarta Selatan, Cilandak Barat, yang dikenal sebagai salah satu kawasan yang di dominasi dengan perkantoran dengan tingkat stress dan depresi yang tinggi. Tujuan dari proyek ini adalah menciptakan sebuah Third Place yang dapat menjadi tempat berkumpulnya masyarakat untuk berkomunitas dan ruang interaksi dengan menggunakan seni secara primer. Metode penelitian yang digunakan dalam penelitian ini adalah Survey Lapangan, Studi Literatur dan Studi Preseden. Hasil penelitian yang didapatkan adalah perancangan bangunan sebagai "Rumah Seni Ruang Terapi". Program utama dalam proyek ini yaitu Planting, Relaxing Space, Drawingin Sand, FoodCourt, Instalation 3D, Chalkzone Wall, Free Drawing Workshop, Exploration Art Acrylic, Floor Drawing dan Art Gallery, Listening Drawing and Reflection Get to Know Self yang bertujuan untuk menghadirkan seni yang merupakan segala perbuatan manusia yang timbul dari hidup perasaannya dan bersifat indah hingga dapat menggerakkan jiwa perasaan manusia untuk memperbaiki diri.
\end{abstract}

\section{Kata Kunci: komunitas; mental; seni; stress; third place}

\begin{abstract}
Stress and Depression are problems that often occur in people's lives. One of the causes is one's habit in spending most of their time working and resting at home and without social activities that can be done every day with other individual, furthermore with the existence of social media that makes humans able to communicate with electronic devices and not meeting directly. The main issue is "Open Architecture as a Third Place" which discusses how to create a place that can become a Third Place as a gathering place for communities to socialize and as an informal public place. Another issue raised is the Art of Therapy as an Access to mental changes in society which increases stress levels differently by using images in form, combining thoughts with one another, struggling alone through an object, movements that can be united with images can be made into an art performance space. The project location is on Jalan RS. Fatmawati Raya in South Jakarta, West Cilandak, which is known as one of the areas that are dominated by offices with high levels of stress and depression. The aim of this project is to create a Third Place that can be a gathering place for the community to provide comments and interaction space using seniors. The research methods used in this research are Field Survey, Literature Study and Precedent Study. The
\end{abstract}


research results obtained are the design of the building as "House of Art Space Theraphy". The main programs in this project are Planting, Lounge, Drawing Art in Sand, FoodCourt, $3 D$ Installation, Chalkzone Wall, Free Drawing Workshop, Acrylic Art Exploration, Floor Drawing and Art Gallery, Listening Pictures and Self-Recognition Reflections that want to be shown to seniors who are all what humans do arising from feelings of life and moving beautifully so as to divert human feelings to improve themselves.

Keywords: art; community; mental; stress; third place

\section{PENDAHULUAN}

Berkembang seiringnya zaman modern ini, banyak manusia yang mengalami stress, kecemasan, dan kegelisahan. Tetapi masih saja ada orang yang berpikir bahwa stress dan depresi bukan benar-benar suatu penyakit. Stress sering terjadi di masyarakat kita dan tidak peduli usia maupun gender. Penyebabnya bisa terjadi dari berbagai macam, mulai dari tekanan finansial, tempat pekerjaan, hubungan personal, hubungan keluarga, hubungan sosial, kondisi fisik, kehilangan, penyakit, dan kegagalan. Stress yang sering dialami juga melalui tahapan yaitu ringan, sedang dan serius yang berujung pada keputusasaan dalam hidup. Menurut World Health Organization, depresi merupakan gangguan mental dengan munculnya perasaan bersalah, kehilangan minat terhadap sesuatu, gejala penurunan mood, tidak nafsu makan, penurunan konsentrasi, kehilangan energi, dan gangguan tidur. Cilandak Barat merupakan salah satu kelurahan yang warganya memiliki tingkat stress yang cukup tinggi. Di bawah ini merupakan data penduduk berdasarkan Jakarta Smart City dengan batasan wilayah penduduk Kelurahan Cilandak Barat.

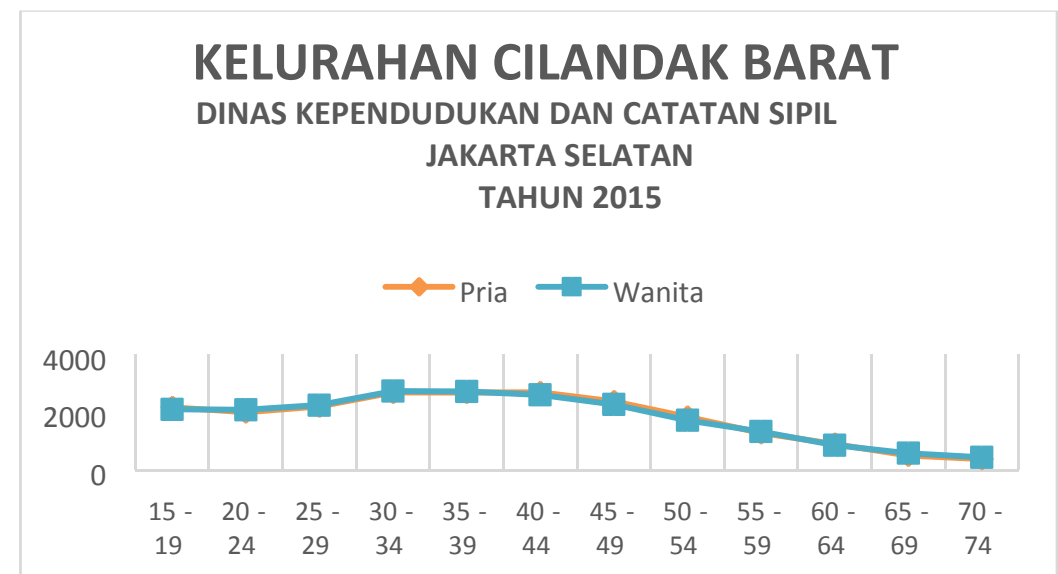

Gambar 1. Data Penduduk Usia Produktif Kerja Terhadap Tingkat Depresi

Penduduk Cilandak Barat

Sumber: https://smartcity.jakarta.go.id, 2015

Stres dan depresi yang dibiarkan berlarut dapat membebani pikiran dan mengganggu sistem kekebalan tubuh. Apabila kita berada dalam emosi yang negatif seperti rasa cemas, putus asa, benci, iri, sedih, dan kurang bersyukur dengan nikmat yang ada, sistem kekebalan akan menjadi lemah. Dalam setiap orang akan mengalami kesulitan hidup dari berbagai apapun. Kemungkinan tersebut dari perasaan yang membuat seseorang menjadi putus asa sehingga terjadi bunuh diri, tetapi dapat terjadi saat memiliki pengalaman depresi sewaktu-waktu. Terkadang dicurahkan dalam beberapa bentuk, dan mengalami pemikiran yang sulit, dan lain sebagainya. Dalam pemenuhan kebutuhan hidup yang kurang dapat mempengaruhi pola pikir dan perasaan stres di era saat ini, maka diperlukan wadah sosial sebagai wadah yang tidak membiarkan manusia semakin terpuruk dan mengabaikan stress sebagai hal yang biasa, tetapi berbicara mengenai bagaimana cara mengontrol stres itu sendiri. Dari hal tersebut, arsitektur 
berbicara tentang cara untuk memenuhi kebutuhan komunitas yang mencampurkan seni sebagai sarana eksistensi mereka. Karena bagaimanapun juga manusia tetap membutuhkan sifat seni dan dilupakan kedalam gambar maupun bentuk sebagai jalan untuk memperbaiki diri. House of Art Space Theraphy hadir sebagai ruang interaksi dengan menggunakan seni secara primer. Secara lebih spesifik, kehadiran proyek juga dimaksudkan untuk menghadirkan seni yang merupakan segala perbuatan manusia yang timbul dari hidup perasaannya dan bersifat indah hingga dapat menggerakkan jiwa perasaan manusia. Dalam hal ini seni juga merupakan produk keindahan yang dapat menggerakkan perasaan indah orang lain yang melihatnya.

\section{KAJIAN LITERATUR}

\section{Definisi Open Architecture: Third Place}

Ray Oledenburg dalam buku yang berjudul "The Great Good place" menyatakan bahwa Third Place merupakan pengaturan inti dalam kehidupan publik informal dan memegang peranan sebagai pembentuk ruang interaksi sosial. Pengertian singkatnya adalah sebagai suatu tempat yang biasa dijadikan tempat berlindung sementara dari kebosanan rutinitas di mana orang akan mendapatkan ketenangan dan kesenangan didalamnya. Third Place merupakan destinasi yang diperuntukan bagi pertemuan antar individu yang bersifar reguler, sukarela, informal, dan diantisipasi oleh khalayak ramai di luar ranah rumah dan pekerjaan. Karakteristik third place didefinisikan sebagai:

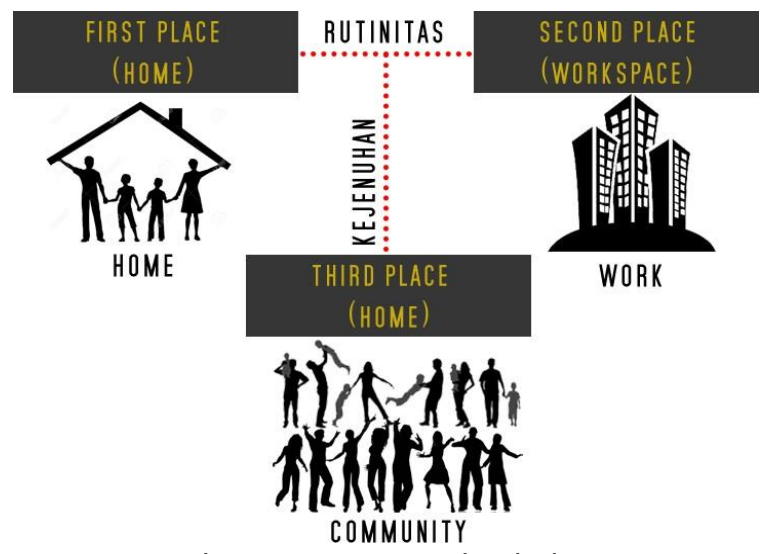

Gambar 2. Diagram Third Place

Sumber: Penulis, 2020

Sebelum revolusi industri terjadi, rumah dan tempat kerja merupakan satu. Setelah terjadinya pembagian zona yang menghilangkan produktivitas dari tempat tinggal terjadilah fenomena di mana cenderung minimnya moralitas dan semangat terhadap kehidupan bersosial. Padahal kebutuhan hidup secara komunal sudah ada jauh sebelum terjadinya pemisahan antara zona privat dan public tersebut. Third Place meredefinisikan manusia sebagai makhluk komunal yang membutuhkan interaksi antara satu dengan lainnya untuk keberlangsungan hidup. Interaksi tersebut diperlukan demi terjadinya pertukaran informasi yang merupakan elemen penting dari proses inovasi yang diperlukan untuk membentuk individu yang sukses.

\section{Definisi dan Hal yang Mempengaruhi Tingkat Depresi}

Menurut M. Heri Susilo pengaruh tingkat depresi adalah gangguan mood (kondisi emosional) berkepanjangan yang mewarnai seluruh proses mental (berpikir, berperasaan dan berperilaku) seseorang dan kesulitan untuk berkomunikasi dengan orang lain seolah ada penghalang yang tampak atau timbul tanpa alasan yang jelas. Depresi dapat diartikan sebagai suatu reaksi yang berlebihan terhadap suatu kejadian yang menjadi pemicunya. Depresi juga dapat diartikan 
suatu jenis alam perasaan atau emosi yang disertai komponen psikologik: rasa susah, murung, sedih, putus asa dan tidak bahagia, serta komponen somatik: anoreksia, konstipasi, kulit lembab (rasa dingin), tekanan darah dan denyut nadi sedikit menurun.

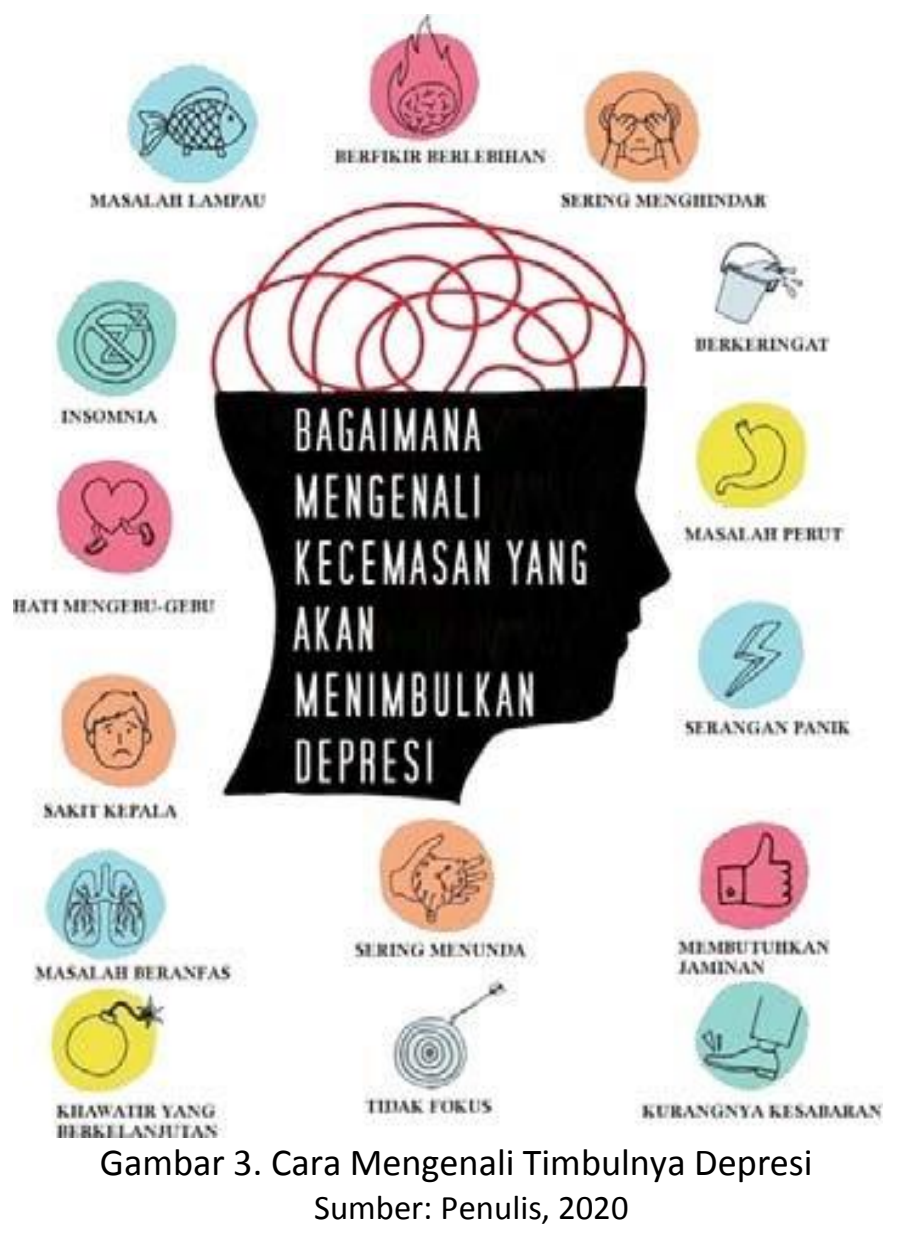

Depresi biasanya terjadi saat stress yang dialami oleh seseorang tidak kunjung reda. Depresi yang dialami ini berkolerasi dengan kejadian dramatis yang baru saja terjadi atau menimpa seseorang. Pada umumnya, mood yang secara dominan muncul adalah perasaan tidak berdaya dan kehilangan harapan. Depresi adalah kata yang memiliki banyak nuansa arti. Sebagian besar di antara kita pernah merasa sedih atau jengkel, menjalani kehidupan yang penuh masalah, merasa kecewa, kehilangan dan frustasi, yang dengan mudah menimbulkan ketidak bahagiaan dan keputusasaan.

B.F. Skinner dan Notoatmodjo teori dengan mengungkapkan hal yang sama yaitu adalah aktivitas manusia namun Notoatmodjo juga menyetujui pendapat Skinner dengan mengutipnya yaitu perilaku terbentuk karena adanya stimulus dari luar. Perilaku pekerja yang hendak 'diobati' atau diubah pada proyek ini adalah tingkat depresi mereka. Perilaku yang menyebabkan depresi di tempat kerja adalah: 


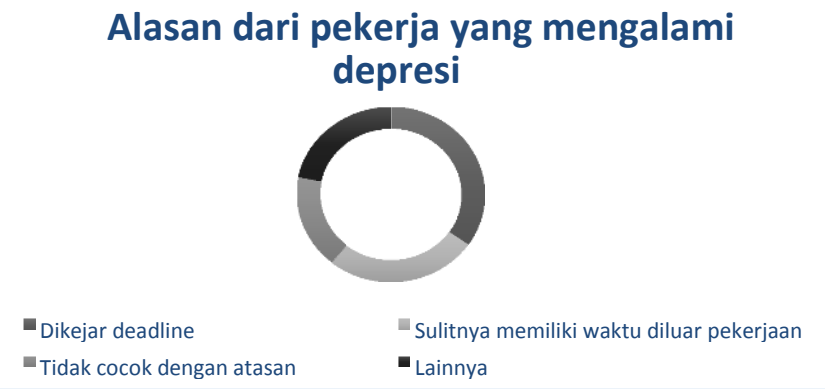

Gambar 4. Diagram Persentase Alasan Pekerja Depresi

Sumber: Penulis, 2020

Alasan lainnya berupa rutinitas; berada di sebuah ruangan terlalu lama; menatap layar laptop berisi pekerjaan sepanjang hari; kurangnya lingkungan yang memberikan efek relaksasi; Kurangnya hiburan.

\section{Penjelasan Terapi Mental Melalui Seni}

Pada buku "Using The Creative Arts in Theraphy And Health Care" Menggunakan seni kreatif dalam terapi dan kesehatan menggunakan seni kreatif dalam terapi dan kesehatan untuk mendorong penyembuhan. Buku ini menggunakan terapi tari, drama, cerita rakyat dan ritual, bercerita dan seni visual. Informasi tentang pedoman, persiapan dan petunjuk praktis untuk para pemimpin dan fasilitator juga telah diperbaharui. Menunjukkan bagaimana seniman dapat meringankan penderitaan bagi pasien melalui seni, musik dan drama. Diilustrasikan di seluruh dengan gagasan dan contoh bagaimana seni dapat digunakan dalam berbagai pengaturan Kesehatan, buku ini akan menjadi bacaan penting bagi terapis seni kreatif dan profesional kesehatan di seluruh dunia. Sehingga mengambil 3 dari beberapa bab yang digunakan dalam konsep bangunan: (Bernie Warren);

\section{Using the visual arts to expand personal creativity}

Pendekatan pribadi yang diperlukan untuk menghasilkan dalam seni visual, ada daerah luas besar eksplorasi batin yang berjalan seiring. Pengalaman batin ini adalah nilai tertentu bagi mereka yang menggunakan seni dengan orang dengan kecacatan. Kebanyakan bentuk seni lainnya memerlukan orang lain untuk memiliki pertemuan penuh dengan apa yang bentuk seni tertentu dapat memberi.

Dance: Developing self-image and self-expression through movement

Gerakan yang memiliki pengulangan dan irama dan dapat dibagi, oleh pengamat luar, ke dalam gerakan tema atau frase. Banyak koreografer modern sering membangun urutan gerakan alam ini untuk menciptakan tarian yang penonton membayar uang untuk menonton. Gerakan yang kita buat sebagai manusia begitu rumit terkait dengan tarian yang dipelajari pihak berwenang menghabiskan berjam-jam berdebat ketika sebuah tindakan, atau serangkaian tindakan, berhenti menjadi gerakan dan mulai memasuki ranah tarian.

\section{Expanding human potential through music}

Musik yang masuk dalam perasaan, kemudian memiliki pusat untuk menahan untuk memungkinkan seseorang untuk bergerak di antara suasana hati yang biasanya dinilai sebagai berlawanan, misalnya kebahagiaan dan kesedihan, yang satu untuk diharapkan dan yang lain dihindari. Dalam pandangan lain bahwa perasaan adalah sumber tindakan, tidak bisa begitu dikendalikan, terutama bagi mereka yang merasa tidak terkendali. Sebaliknya, tubuh harus latihan yang berarti untuk mengakomodasi semua perasaan dengan kemampuan untuk melampaui orang yang membuktikan tidak menyenangkan. 


\section{METODE}

\section{Metode Analisis}

Metode yang digunakan adalah metafora tangible dan intangible berdasarkan buku "Poetic of Architecture: Theory of Design " oleh Antoniades dan dikombinasikan dengan buku "The Language of Architecture" oleh Andrea Simitch sebagai acuan dalam mempertahankan sebuah prinsip-prinsip arsitektur kedalam bentuk bangunan, kemudian yang dapat dikaitkan dengan metode ini yakni "Using The Creative Arts in Theraphy And Health Care" oleh Bernie Warren dimana fungsi program yang membentuk ruang dalam dengan tinggi rendah lantai yang telah di metaforakan terhadap bangunan. Bentuk metafora diterjemahkan ke bangunan yakni dengan menerapkan bentuk kupu-kupu yang menjadikan suatu bentuk atap segitiga yang diadaptasi dengan beberapa prinsip seperti: Building codes, Characteristic, Komponen, Representation, Konsep, dan Orientasi diagram. Pemilihan prinsip yang menunjang sebagai acuan untuk memperkuat program desain dengan perbedaan plat lantai dengan menggunakan ramp pada setiap level. Pembentukan void yang bebeda dengan prinsip representation dengan tumpang tindih plat lantai dan sudut berbeda sebagai cahaya masuk. Dimensional, fungsional, orientasi pada dalam bangunan membuat ruangan menjadi lebih nyaman sehingga pengguna dengan gangguan mental dapat menggunakan ruang secara baik. Penggunaan material pada bangunan dengan penyatuan warna kayu, hijau, concrete, batu alam sebagai acuan dalam program yang memiliki arti alam yang berdeketan dengan manusia.

\section{Metode Pengumpulan Data}

Metode studi lapangan ini digunakan sebagai studi yang membantu penulis dalam menganalisis langsung tapak yang telah terpilih. Studi lapangan dilakukan pertama kali pada bulan Januari 2020 untuk mencari sebuah permasalahan yang ada di dalam kawasan dalam mendata kondisi bangunan sekitar sebagai memulai proses perancangan proyek. Pada bulan februari 2020, penulis melakukan studi kembali untuk meninjau lebih lanjut tapak yang terpilih apakah sesuai dengan kriteria perancangan yang berhubungan dengan program yang akan dicanangkan dalam proyek ini. Survei berdekatan dengan MRT yang menjadikan lahan tapak sebagai tempat untuk memperbaiki diri dan sebagai diantar perkantoran maupun hunian. Eksisting tapak dengan lahan hijau kosong yang dapat dijadikan suatu pembangunan yang akan difungsikan sesuai dengan peraturan pemerintah, dan di kelilingi dari bangunan komersil di bagian sebelah tapak juga hunian di bagian belakang tapak.

\section{DISKUSI DAN HASIL}

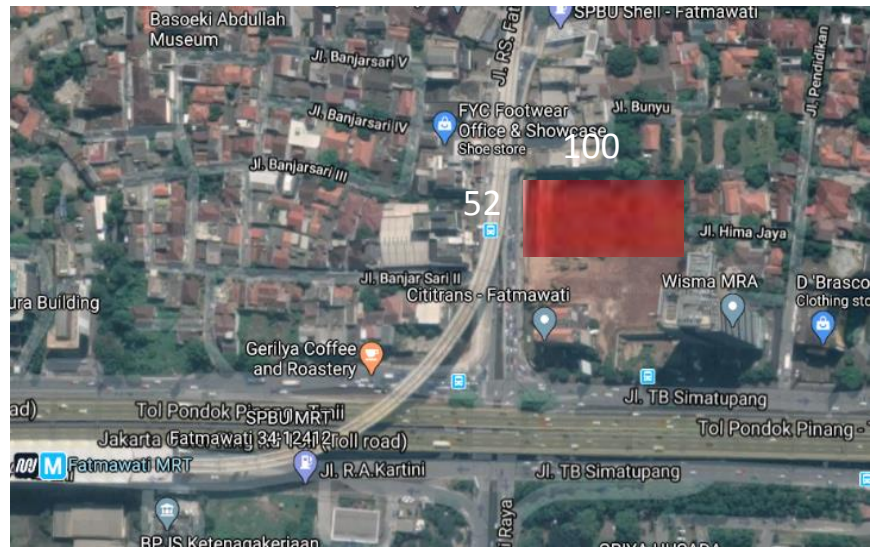

Gambar 5. Tapak Terpilih

Sumber: Google Maps, 2020

Keadaan eksisting pada tapak yaitu berupa tanah kosong. Pada pengamatan (survey tapak), kondisi jalan depan tapak (JL. RA Kartini) memiliki Kriteria seperti: Lebar jalur Jalan RS Fatmawati adalah +/- $10 \mathrm{~m}$, Untuk bagian depan tapak terdapat 2 lajur jalan, dan jalur MRT, 
kemudian Intensitas kemacetan tinggi pada jalan RS Fatmawati, disebabkan oleh antrian lampu merah yang dekat dengan persimpangan dan aktivitas pergerakan manusia dari stasiun MRT yang menyebabkan timbulnya banyak ojek online.

Jalur pedestrian yang berukuran +/- $1.7 \mathrm{~m}$, kurang seimbang dengan banyaknya aktivitas pergerakan manusia dari stasiun MRT dan bangunan sekitar. Terlihat juga bahwa belum diterapkannya street furniture seperti lampu pejalan kaki, tempat duduk, tempat sampah dan vegetasi. Ditemukan juga banyak pedagang kaki lima dan ojek online yang berkumpul di pinggir jalan disekitar tapak terpilih. Pada kawasan ini belum tersedia area untuk ojek online menunggu dan area drop off.

\section{Analisis Tapak}
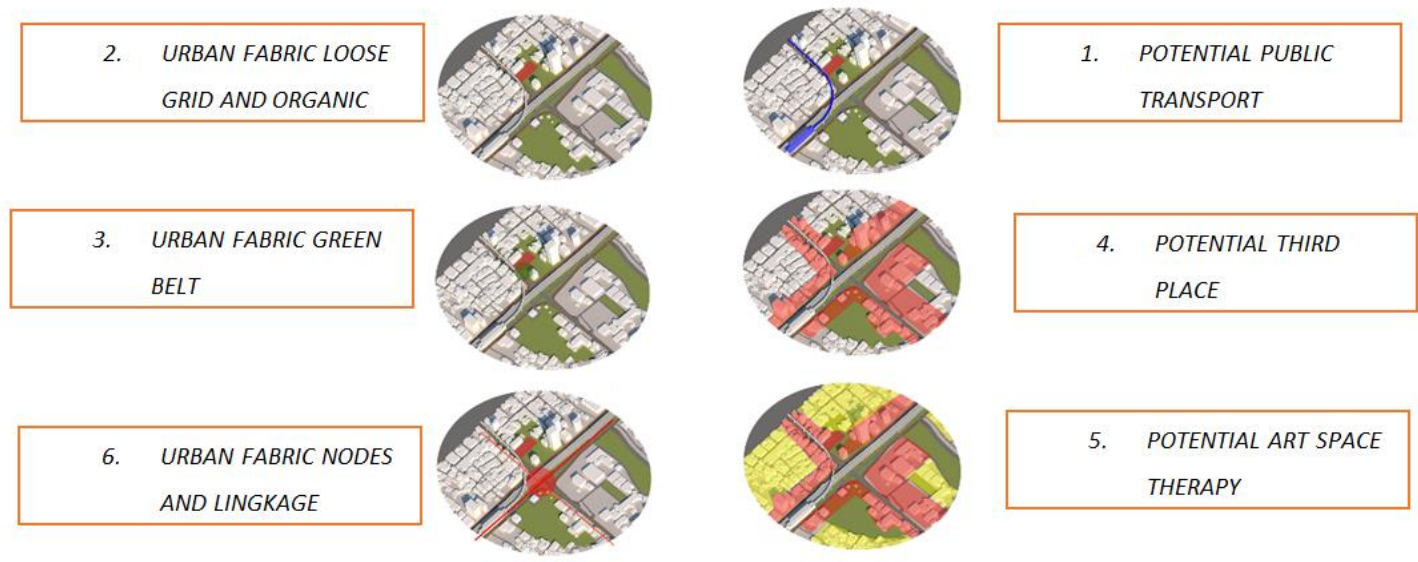

Gambar 6. Analisa tapak

Sumber: Penulis, 2020

Kawasan di sekitar tapak memiliki konteks urban fabric loose grid dan organic, di mana terlihat dari bentuk jalan yang ada, hal ini memungkinkan untuk membentuk massa bangunan yang memiliki pattern baru. Memperkuat konsep greenbelt di dalam tapak untuk memberikan konsep penghijauan yang mulai tersingkirkan di area sekitar tapak. Tapak berada di jalan kolektor (JI. RS. Fatmawati) yang dekat persimpangan padat antara JI. RS. Fatmawati dengan Jl. TB Simatupang, hal ini tentunya akan berpengaruh pula terhadap jumlah pengunjung yang akan datang ke area tapak menjadi berpotensi ramai. Tapak berada di dekat stasiun MRT Fatmawati, dan dilalui juga oleh jalur MRT. Selain itu, area sekitar tapak dilalui oleh kendaraan umum lain seperti Transjakarta, angkutan kota, dan bus kota, sehingga untuk transportasiumum yang tersedia sudah sangat memadai, karena banyak pilihan transportasi yang dapat digunakan untuk dapat mencapai tapak. Karena berada di area perkantoran dan pemukiman yang padat, tapak dapat menjadi sebuah tempat yang strategis untuk menjadi sebuah third place bagi para pekerja maupun masyarakat sekitartapak yang sedang jenuh atau stress dalam menjalani aktivitas sehari-harinya dengan mobilitas yang tinggi. Perkantoran dan pemukiman yang padat dengan mobilitas yang cukup tinggi, sehingga tingkat stress yang ada juga cukup tinggi. Art space theraphy akan dapat menjadi sebuah sarana penghilang stres tersebut.

\section{Proses Gubahan Massa}

Setelah melakukan analisis terhadap tapak, selanjutnya akan dibuat proses gubahan massa yang sesuai dengan konteks lingkungan. 

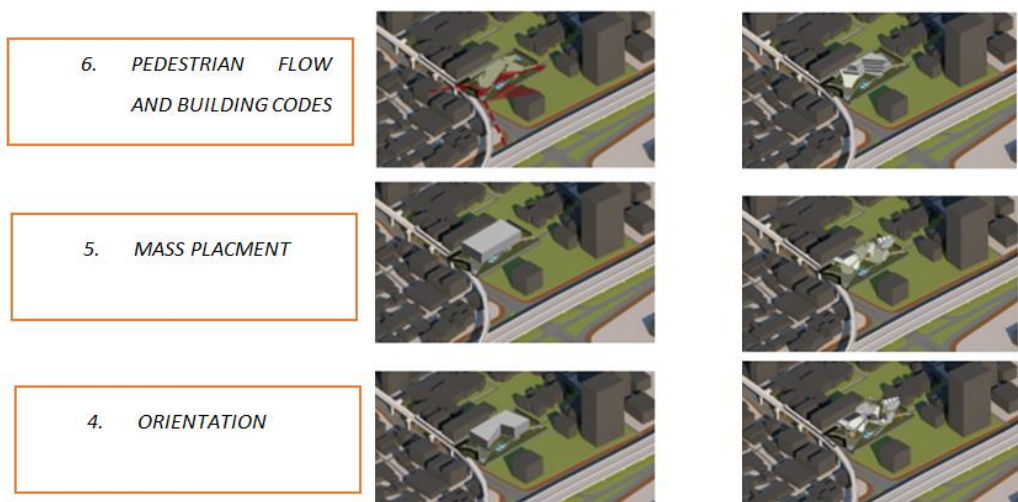

3. MASS DISTORTION
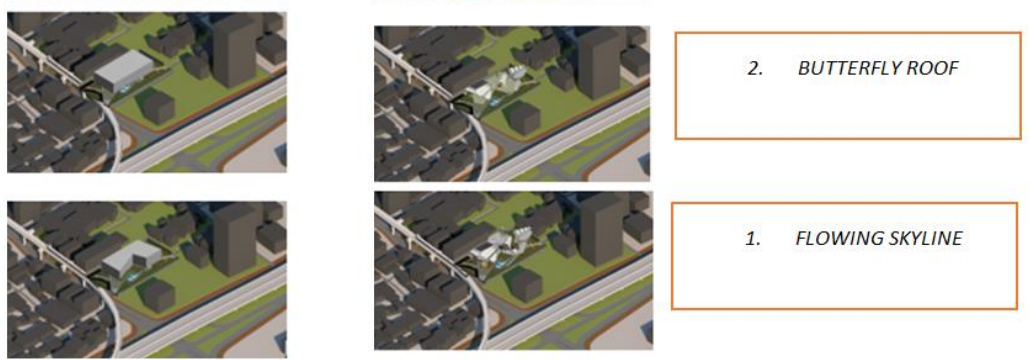

1. FLOWING SKYLINE

Gambar 7. Proses Gubahan Massa

Sumber: Penulis, 2020

Berdasarkan analisa di atas, dalam gubahan dengan tapak menggunakan proses Pedestrian flow and building codes masuknya flow pedestrian dari arah barat daya lebih dominan, dan permainan naik turun pada tanah menjadikan sebuah dimensi pada denah ground floor. Mass placment menggunakan massa bangunan yang disesuaikan dengan geometri tapak sesuai dengan peraturan GSB pemerintah. Orientation dengan massa yang dipotong pada bagian sisi selatan yang cocok sebagai arah jarak pandang dari MRT dan jalan tol lebih mendominasi. Kemudian mass distortion dengan perubahan bentuk yang bertujuan untuk lebih menonjolkan karakteristik visual Massa, sehingga mendapatkan bentuk menjadi sempurna, yang sesuai dengan konsep estetik seni. Butterfly roof sebagai penambahan atap yang bisa dijadikan sebagai dinding massa yang memiliki karakteristik, terdapat hologram pada saat malam hari sebagai tanda corak kupu-kupu. Flowing skyline massa yang disesuaikan dengan ritme skyline yang naik turun dan massa yang menggambarkan sedang merangkul kawasan yang membutuhkannya.

\section{Analisis Program Ruang}

Dari diagram di bawah, terdapat dari 13 program utama yaitu Planting, Relaxing Space, Drawing Art in Sand, FoodCourt, Instalation 3D, Chalkzone Wall, Free Drawing Workshop, Exploration Art Acrylic, Floor Drawing dan Art Gallery, Listening Drawing and Reflection Get to Know Self. Di ambil dari yang terpenting program Planting merupakan program yang memberikan edukasi pada pemanfaatan penanaman dan juga dapat difungsikan sebagai cat warna dengan berbagai jenis warna pada aktifitas di dalam dalam membangun mental pengunjung. Relaxing Perfomence sebagai wadah program untuk bersantai, bebas dan menenangkan melalui media musik dan pentas seni yang ditunjukan. Drawing in Sand yang merupakan tarian yang dikombinasikan dengan gambar sehingga lebih komplek dapat dilihat dari gerak dan gambar yang mengartikan perasaan penari dan penyampain pesan tersebut. FoodCourt sebagai wadah penunjang untuk memenuhi semua kebutuhan dari selingan aktifitas pendatang. Instalation 3D merupakan bentuk yang dihasilkan dari gambar menjadikan bentuk $3 \mathrm{D}$ sesuai dengan syarat.

Chalkzone Wall merupakan program menggambar di dinding yang kegiatan tersebut lebih fokus pada anak-anak yang didampingi oleh volunter. Free Drawing and Workshop sebagai wadah pertama masuk dalam awal permulaan dengan menggambar secara bebas, baik bermasalah secara mental maupun tidak. Exploration Art Acrylic merupakan Aktifitas gambar pada kaca acrylic dengan sentuhan penyemprotan warna secara bebas dengan plat lantai yang dapat dibersihkan. Floor Drawing sebagai program gambar dibawah lantai dengan media kertas besar yang dapat digunakan oleh beberapa orang dengan tarian perasaan yang lebih diaplikasikan oleh orang dewasa. Art Gallery sebagai akses gambar yang dapat dilihat yang 
dihasilkan dari mental rendah yang dapat terealisasikan pada gambar tersebut. Listening and Drawing yang dapat digunakan sebagai gambar melalui media musik apapun baik metal, sedih maupun tenang. Reflection Get to Know self merupakan wadah sharing yang setiap orang dapat berkomunikasi melalui ruangan tersebut dan berkaca pada dinding tajam yang dijadikan sebagai untuk mengetahui diri lebih.
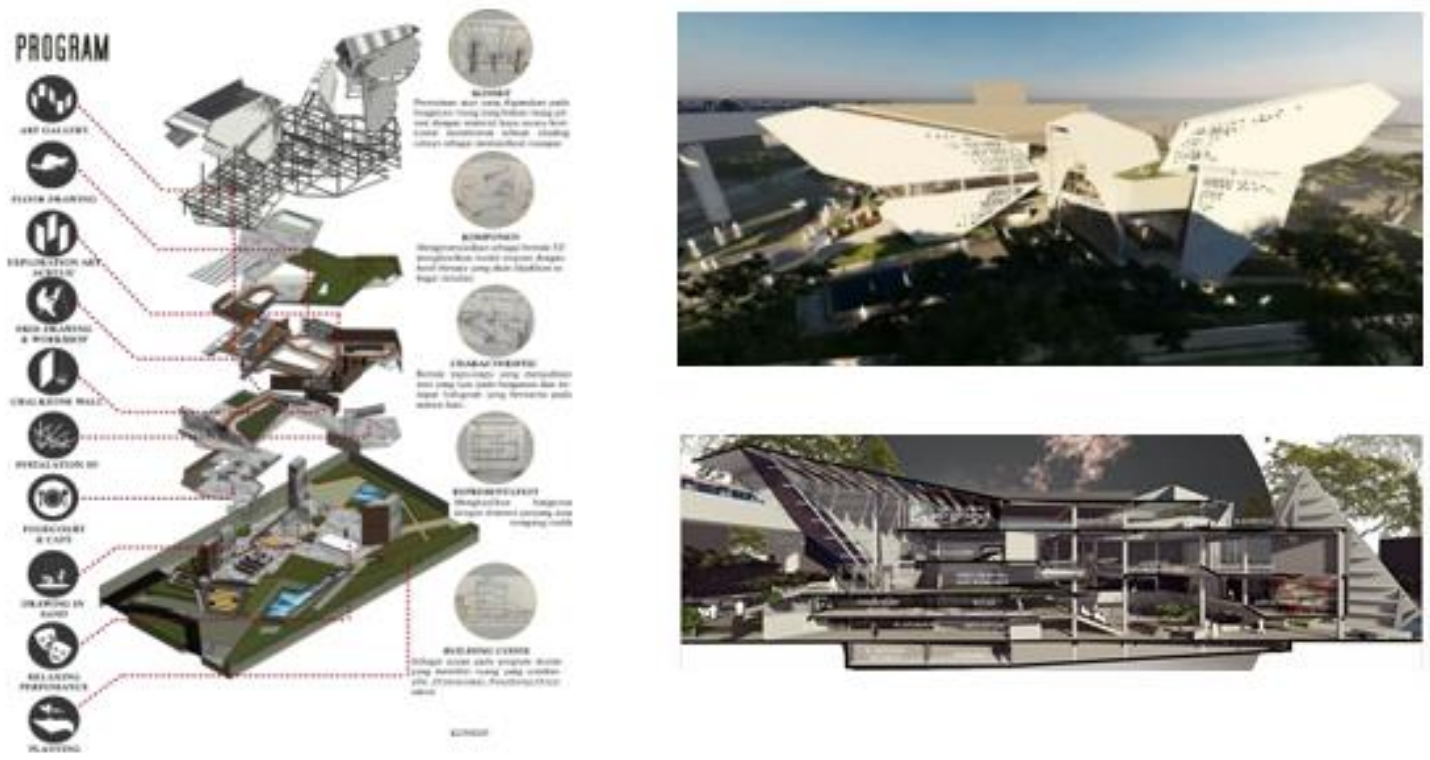

Gambar 8. Program Diagram Axonometri, Konsep dan Potongan 3D Sumber: Penulis, 2020

Bentuk bangunan disesuaikan dengan ciri khas kupu-kupu yang menjadikan sebuah bentuk sederhana yang mudah di kenal dan dipahami, kemudian bagian dalam ruang tersebut memiliki program yang luas, dengan atap miring dan tajam yang berbeda dengan yang lain, yang menjadikan wadah yang dibutuhkan oleh lingkungan sekitar sebagai wadah penyembuhan diri.

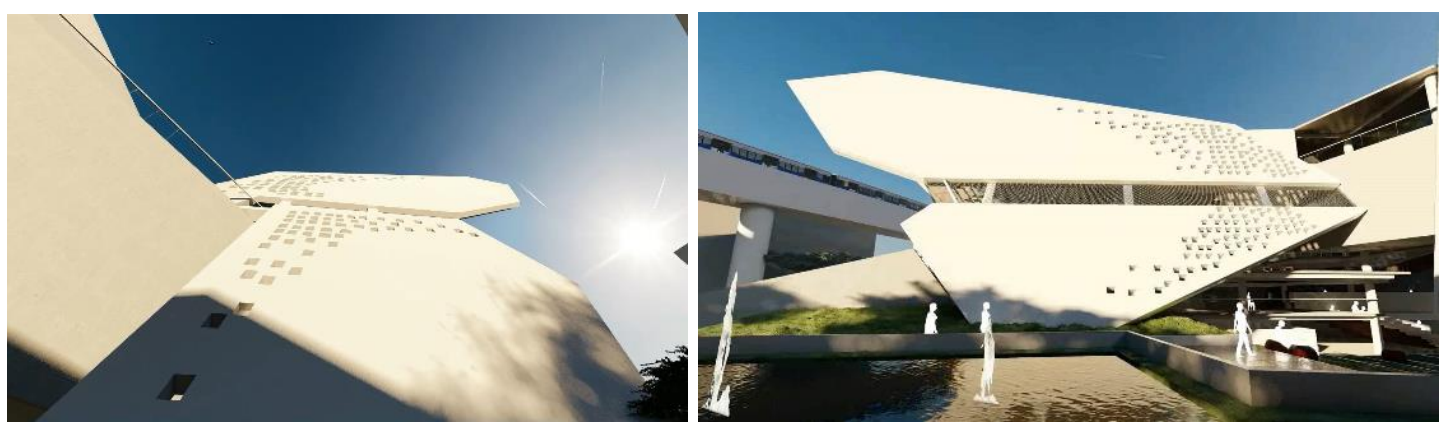

Gambar 9. Facade dan Material

Sumber: Penulis, 2020

Facade bagian depan yang menggambarkan atap Toraja dan sisi samping yang membentuk facade segita yang dihasilkan dari sayap kupu-kupu dengan bahan atap bitumen yang berbahan aspal berwarna putih, kemudian dapat di tembak dengan projector yang menjadikan dinding sebagai holographic wall dengan perpaduan warna maupun cerita pada dinding atap tersebut. 


\section{Deskripsi Proyek}
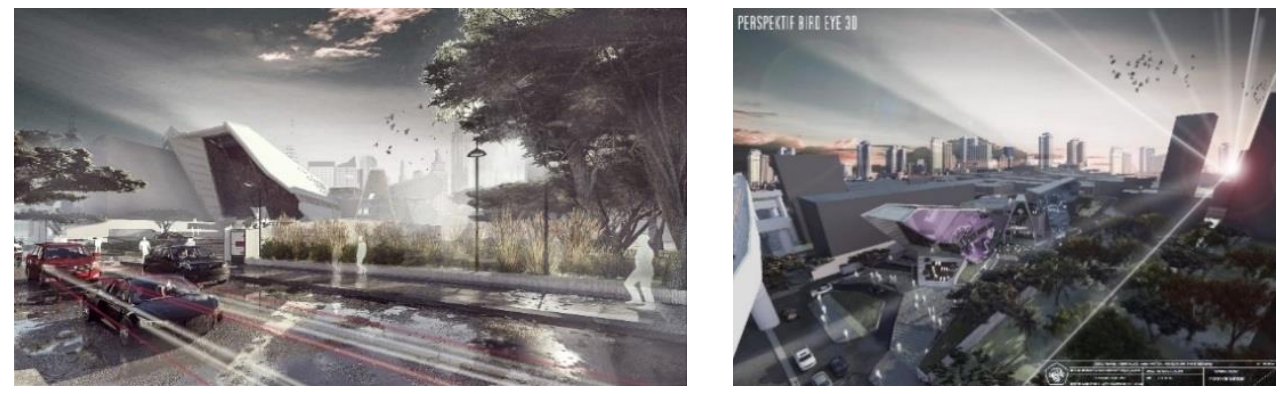

Gambar 10. Eksterior dan Bird Eye

Sumber: Penulis, 2020

Proyek ini didesain dengan sederhana yang mudah diingat dan dikenal karena bentuk tersebut dibentuk dari konsep kupu-kupu dengan sentuhan sedikit arsitektur yang membuat bangunan tersebut terlihat sederhana, kecil dibandingkan bangunan besar yang ada pada lingkungan sekitar. Pada bagian depan memiliki akses yang kuat pada sisi pintu masuk yang sesuai dengan Third Place, yang menandakan selamat datang dengan bukaan yang sangat luas dan bisa digunakan oleh disabilitas dengan menggunakan jalur ramp pada setiap pencapaian program sehingga semua kalangan dapat menggunakan bangunan tersebut dengan mudah.
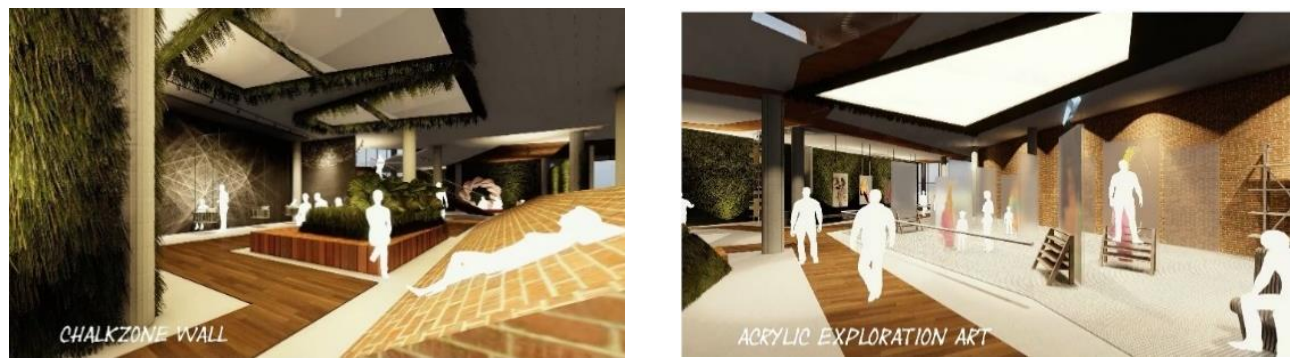

Gambar 11. Interior: Chalkzone Wall dan Acrylic Exploration Art

Sumber: Penulis, 2020

Chalkzone Wall di lantai dasar 1B yang dibuat memiliki kursi gantung yang dapat bergeser, naik-turun dengan menggunakan mesin katrol yang dapat bergerak pada bagian atas, sebagai wadah yang digunakan untuk menggambar pada dinding dengan menggunakan alat kapur. Terdapat tempat menunggu pada bagian tengah ruang dan bagian sisi dengan railing beton miring yang dapat dijadikan wadah istirahat dengan kemiringan tertentu. Ruang Exploration Art Acrylic yang menggunakan media kaca acrylic, tangga kecil untuk anak-anak, dan plat lantai metal expanded sebagai lantai yang dapat dibersihkan. Ruangan tersebut memiliki perbedaan lantai dengan menggunakan ramp sebagai akses yang mudah dan nyaman, juga terdapat kursi tunggu pada bagian depan ruang.

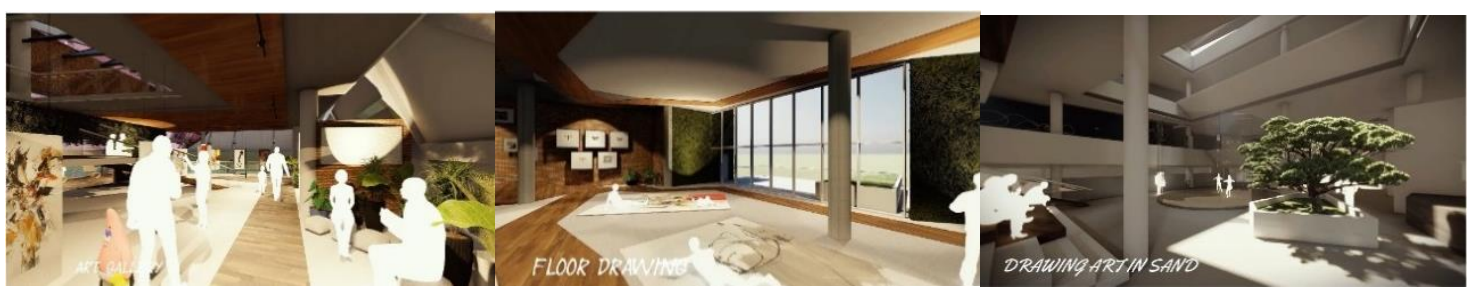

Gambar 12. Interior: Art Galley, Floor Drawing dan Drawing Art in Sand

Sumber: Penulis, 2020 
Pada lantai 3, Art Gallery berfungsi sebagai ruang yang dihasilkan dari karya-karya terpilih yang sesuai dengan syarat seperti mental stress yang tinggi kemudia teraplikasi menjadikan sebuah seni gambar yang menyentuh. Dan pada bagian sisi terdapat ruang sharing yang dapat belajar pada sesorang yang berhasil keluar dari mental stress tinggi dan memberikan solusi untuk pendatang baru yang mengalami hal sama. Pada lantai 2, terdapat Floor Drawing yang menggunakan kertas besar dengan aktifitas gambar yang luas dengan beberapa orang yang memiliki tarian pada bawah lantai, yang mengkombinasikan perasaan seorang satu dengan yang lainnya yang membentuk sebuah seni. Sebagai wadah program yang dipertunjukan kepada semua orang dengan tangga yang dapat dijadikan ruang duduk, untuk menonton pentas seni maupun tarian gambar dengan ruang kaca private tanpa menggangu pengguna.

\section{KESIMPULAN DAN SARAN}

Stress dan Depresi merupakan permasalahan yang ada didalam kehidupan saat ini, yang diperlukan adalah wadah third place sebagai tempat dalam memenuhi kebutuhan untuk meringankan beban masyarakat di Cilandak Barat. Cilandak Barat sebagai kawasan yang dapat menerima masyarakat yang memiliki depresi, wadah ini menjadi tantangan bagi masyarakat untuk meningkatkan kesejahteraan dan pemulihan agar masyarakat kembali normal. Kawasan yang kurang dari tempat hiburan dan pusat bisnis dengan pola kerja yang berulang akan mengalami depresi.

Banyaknya usia produktif di Kelurahan Cilandak Barat serta keingintahuan tentang mempelajari hal baru, membutuhkan fasilitas edukasi yang memadai atau third place. Sebagai third place dalam memfasilitasi dan memenuhi kebutuhan masyarakat, akan dirancang 'House of Art Space Theraphy. Third place pada Kelurahan Cilandak Barat, akan menawarkan third place dengan kategori Refresment. Tempat di mana masyarakat akan mengulang dirinya menjadi lebih baik pada kesehatan mental yang merubah fisik masyarakat dan mengurangi tingkat bunuh diri. Third place sebagai tempat bersenang-senang dan belajar di mana semua berkumpul, baik introver maupun masyarakat yang mengalami depresi dapat meluapkan, mengekspresikan, menenangkan pikiran menjadi lebih baik dan terdapat hiburan.

\section{REFERENSI}

Antoniades, A. C. (1992). Poetics of Architecture: Theory of Design. New York City: Willey.

Oldenburg, R. (1989). The Great Good Place: Cafes, coffee shops, bookstores, bars, hair salons and other hangouts at the heart of community. Philadelphia: Da Capo Press.

Rachmi/sir. (2013), September 29. RW 03 Cilandak Barat Maju ke Tingkat DKI. Retrieved March 23, 2020, from POSKOTANEWS: http://poskotanews.com/2013/09/29/rw-03cilandak-barat-maju-ke-tingkat-dki/

Simitch, A. (2014). The Language of Architecture: 26 Principle every architect should know. Andrea Simitch + Val Warke.

Skinner, B.F, Notoatmodjo. (2007). Merumuskan perilaku sebagai respons atau reaksi seseorang terhadap stimulus (rangsangan dari luar), membagi perilaku manusia ke dalam tiga domain dari sudut pandang kesehatan.

Warren, B. (2008). Using The Creative Arts in Theraphy and Healthcare: Art therapy, Drama therapy, Music therapy, Dance therapy, Play therapy. 
